(C) 2019. This manuscript version is made available under the CC-BY-NC-ND 4.0 license http:// creativecommons.org/licenses/by-nc-nd/4.0/

\title{
Simultaneous nitrification, denitrification and phosphorus recovery (SNDPr) - An opportunity to facilitate full-scale recovery of phosphorus from municipal wastewater
}

Sara Salehi ${ }^{\mathrm{a}, \mathrm{b}}, \mathrm{Ka}$ Yu Cheng ${ }^{\mathrm{a}, \mathrm{c}}$, Anna Heitz $^{\mathrm{b}}$, Maneesha P. Ginige ${ }^{\mathrm{a}^{*}}$

${ }^{a}$ CSIRO Land and Water, Floreat, Western Australia, 6014, Australia.

${ }^{\mathrm{b}}$ Department of Civil Engineering, Curtin University, Bentley, Western Australia, 6102, Australia.

${ }^{\mathrm{c}}$ School of Engineering and Information Technology, Murdoch University, Murdoch, Western Australia 6150, Australia.

*Corresponding author. Tel: +61 89333 6130; Fax: +61 893336499.

E-mail address: Maneesha.ginige@csiro.au 


\section{Highlights}

- Carbon in wastewater is adequate for nitrogen $(\mathrm{N})$ removal and phosphorus $(\mathrm{P})$ recovery

- Simultaneous nitrification denitrification \& P removal (SNDPR) enables P recovery

- Dissolved oxygen $<0.5 \mathrm{mg} / \mathrm{L}$ critical for a balanced microbial community in granules

- Polyphosphate accumulating organisms showed highest affinity towards oxygen

- Glycogen accumulating organisms played a role in SNDPR, specifically to remove $\mathrm{N}$ 


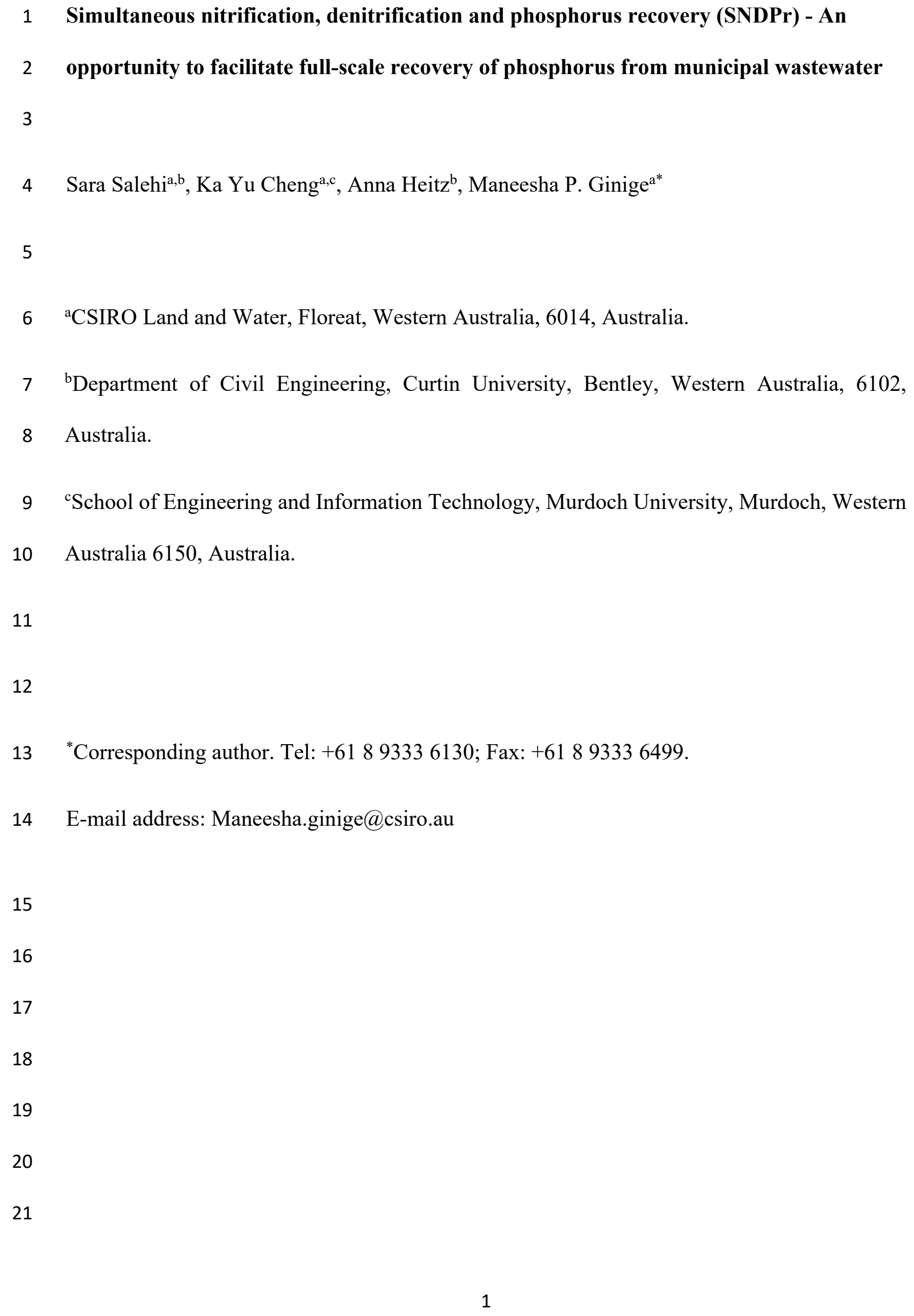




\section{Abstract}

Sewage treatment plants are a potential point source for recycling of phosphorus $(\mathrm{P})$. Several technologies have been proposed to biologically recover P from wastewater. The majority of these technologies are side-stream processes and rely on an external source of soluble organic carbon to facilitate P recovery. To date, no studies have demonstrated the potential to facilitate main-stream recovery of $\mathrm{P}$, using carbon that is naturally present in wastewater. Simultaneous nitrification, denitrification and phosphorus removal (SNDPR) is an elegant process that can uptake influent carbon and effectively remove both nitrogen $(\mathrm{N})$ and $\mathrm{P}$ from wastewater. SNDPR studies to date, however, have failed to facilitate a $\mathrm{P}$ rich liquor end-of-anaerobicphase, that enables economies of scale to recover influent $\mathrm{P}$. Therefore, this study examined the feasibility of achieving a P rich liquor (e.g. $>70 \mathrm{mg}-\mathrm{P} / \mathrm{L}$ ) with granular SNDPR process. A synthetic influent that replicated the nutrient and carbon concentrations of municipal wastewater was used to investigate whether carbon in the influent wastewater could enable both nutrient removal and P recovery from wastewater. Our granular SNDPR process was able to facilitate a $\mathrm{P}$ rich liquor of approximately $100 \mathrm{mg}-\mathrm{P} / \mathrm{L}$ end-of-anaerobic-phase. A dissolved oxygen (DO) concentration of $0.5 \mathrm{mg} / \mathrm{L}$ in a sequencing batch reactor (SBR) was found to be essential to achieve complete nutrient removal and a high $\mathrm{P}$ concentration at the end of the anaerobic phase. At this steady state of reactor operation, the abundance of polyphosphate accumulating organisms (PAOs) was 2.6 times the abundance of glycogen accumulating organisms (GAOs). The study also demonstrated the importance of denitrifying polyphosphate accumulating organisms (DPAOs) and glycogen accumulating organisms (DGAOs) to achieve complete removal of $\mathrm{N}$ from the effluent. Compared to nitrifying bacteria, the polyphosphate accumulating organisms (PAOs) had a higher affinity towards DO. This study, for the first time, showed that the mainstream recovery of $\mathrm{P}$ is feasible using a SNDPR process. 
47 Keywords: Phosphorus recovery, Polyphosphate accumulating organisms (PAOs),

48 Denitrifying polyphosphate accumulating organisms (DPAOs), Simultaneous nitrification, 49 denitrification and phosphorus removal (SNDPR).

\section{Introduction}

Modern agricultural practices are highly reliant on phosphorus $(\mathrm{P})$ to achieve high crop yields.

$\mathrm{P}$ however, is a non-renewable resource and depletion of $\mathrm{P}$ reserves is likely in the next $50-$ 100 years (Shu et al., 2006). With the aim of reducing pressures on mining, there has been considerable interest on processes for $\mathrm{P}$ recycling in the recent past. Municipal wastewater treatment plants are a key point source for recycling of $\mathrm{P}$ (Cordell et al., 2009). However, the economics of P-recovery from this source are not encouraging due to the low concentrations typically found in influent wastewater $(<10 \mathrm{mg}-\mathrm{P} / \mathrm{L})$ (Cieslik and Konieczka, 2017). Current $\mathrm{P}$ recovery techniques (e.g. as struvite) require concentrated streams containing at least 50 $\mathrm{mg} / \mathrm{L}$ of $\mathrm{P}$ and research thus far has focused on developing strategies to concentrate $\mathrm{P}$ within wastewater treatment processes (Yuan et al., 2012).

All biological strategies developed to generate a concentrated stream of P from municipal wastewater, have thus far exploited the metabolic processes of polyphosphate accumulating organisms (PAOs). PAOs, are the driving force in enhanced biological phosphorus removal (EBPR) and have a unique metabolism. When exposed to aerobic or anoxic conditions, the PAOs uptake orthophosphate $\left(\mathrm{PO}_{4}{ }^{3-}\right)$ from the surrounding environment and store it 67 intracellularly as poly-P (Tarayre et al., 2016; Yuan et al., 2012). The P uptake takes place with a simultaneous oxidation of intracellular polyhydroxyalkanoates (PHA) (Lee et al., 2001). This 69 results in a net removal of $\mathrm{PO}_{4}{ }^{3-}-\mathrm{P}$ from municipal wastewater. When PAOs with intracellular 70 poly-P are exposed to a soluble organic carbon (C) source (e.g. acetate) under anaerobic 71 conditions, carbon reserves are replenished, utilising energy derived from hydrolysis of the 
72 stored poly-P (Kapagiannidis et al., 2013). As a consequence, $\mathrm{PO}_{4}{ }^{3-}-\mathrm{P}$ is released back into the 73 environment (Chuang et al., 1996). Wong et al. (2013) strategically facilitated this second step

of the EBPR process in a separate smaller volume of liquid and, based on this principle, they developed a method to achieve a concentrated P stream. With repeated use of this recovery stream in the EBPR process, the authors were able to achieve a P concentration of up to 100 mg-P/L. Wong et al. (2013) combined this P recovery strategy with post denitrification to maximise the use of carbon, not only to promote nitrate removal but also for the recovery of $\mathrm{P}$ from wastewater.

The need to add external carbon to facilitate post-denitrification presents a significant operational cost to the wastewater industry. Hence, the wastewater industry is constantly examining strategies to maximise the use of naturally abundant carbon in municipal wastewater to remove both nitrogen $(\mathrm{N})$ and $\mathrm{P}$ from wastewater. Simultaneous nitrification-denitrification and $\mathrm{P}$ removal (SNDPR) is an elegant process that can achieve biological nutrient removal from wastewater at a lower carbon demand (Zeng et al., 2003). In SNDPR, N removal largely takes place via the nitrite pathway. It has been demonstrated that both denitrification and $\mathrm{P}$ removal take place with the aid of denitrifying PAOs (DPAOs, use nitrate or nitrite as final electron acceptors for P uptake) or denitrifying glycogen accumulating organisms (DGAOs, use nitrate or nitrite as final electron acceptors). The abundance of both the nitrite pathway (for $\mathrm{N}$ removal) and DPAOs (for both denitrification and P removal) in SNDPR, significantly reduces the demand for oxygen, decreasing aeration costs. This, in turn, helps conserve naturally occurring carbon, enabling its use to successfully remove both $\mathrm{N}$ and $\mathrm{P}$ from wastewater (Wang et al., 2015; Zeng et al., 2003).

There are many studies that have demonstrated the effectiveness of SNDPR to remove C, N, and P to very low levels (Table 1). However, none have demonstrated that SNDPR could facilitate P recovery, using the carbon naturally present in wastewater. Among lab-scale studies 
97 carried out, there are only a handful of studies that have used a synthetic feed that resembled 98 municipal wastewater in terms of $\mathrm{C}, \mathrm{N}$ and $\mathrm{P}$ concentrations. Moreover, these studies only achieved low $\mathrm{P}$ concentrations at the end of the anaerobic phase (P release). Further, the incomplete removal of $\mathrm{N}$ and $\mathrm{P}$ also raise questions on whether $\mathrm{P}$ recovery from municipal wastewater containing low $\mathrm{C}$ concentrations could actually be achieved without the need for external C. For example, even with a higher concentration of $\mathrm{C}$ (chemical oxygen demand (COD) $400 \mathrm{mg} / \mathrm{L}$ ) in the influent, Wang et al. (2016b) only achieved a P concentration of $\sim 25$ $\mathrm{mg} / \mathrm{L}$ at the end of the anaerobic phase of their reactor cycle. Similarly, Jia et al. (2013b) only achieved a $\mathrm{P}$ concentration of $17 \mathrm{mg} / \mathrm{L}$. Nonetheless, several non-SNDPR lab-scale studies have proven the feasibility of achieving higher $\mathrm{P}$ concentrations $(\sim 100 \mathrm{mg}-\mathrm{P} / \mathrm{L})$ using low COD (e.g. $200 \mathrm{mg} / \mathrm{L})$ and P (10 mg/L) concentrations in the influent (Barat et al., 2008). However, since these studies ignored nitrogen removal (by using a nitrification inhibitor (allyl$\mathrm{N}$ thiourea)), it still remains unclear whether low COD concentrations could facilitate simultaneous $\mathrm{N}$ removal and P recovery.

111 The aim of this study was to explore the use of a granular SNDPR process to recover influent $112 \mathrm{P}$ in a very small volume as a highly-concentrated $\mathrm{P}$ liquor (e.g. recovery of $10 \mathrm{mg}-\mathrm{P}$ that is in $1131 \mathrm{~L}$ of influent in a volume of $100 \mathrm{ml}$ (concentration - $100 \mathrm{mg}-\mathrm{P} / \mathrm{L}$ )). There is a natural release 114 and uptake of $\mathrm{PO}_{4}{ }^{3-}-\mathrm{P}$ during SNDPR operation and the study aimed to optimise the SNDPR 115 process to maximise $\mathrm{PO}_{4}{ }^{3-}-\mathrm{P}$ release during the anaerobic phase of the sequencing batch reactor 116 (SBR) cycle. As previously mentioned, SNDPR studies with $\mathrm{C}, \mathrm{P}$ and $\mathrm{N}$ ratios of a typical 117 wastewater influent have only managed to achieve $\mathrm{PO}_{4}{ }^{3-}-\mathrm{P}$ concentrations of $70 \mathrm{mg}-\mathrm{P} / \mathrm{L}$ during 118 anaerobic $\mathrm{P}$ release. Higher $\mathrm{P}$ concentrations have only been achieved with influent $\mathrm{C}$ 119 concentrations greater than $400 \mathrm{mg}-\mathrm{COD} / \mathrm{L}$ (Jia et al., 2013b; Zeng et al., 2003). Such high 120 concentrations of $\mathrm{C}$ in the influent are not observed in typical municipal wastewater (Azizi et 121 al., 2013). Hence, this study specifically examined the feasibility to use typical municipal 
wastewater carbon concentrations to achieve higher release of $\mathrm{PO}_{4}{ }^{3-}-\mathrm{P}$ during the anaerobic phase of reactor operation.

A laboratory-scale SBR reactor was operated for a period of 4 months under alternating anaerobic / aerobic conditions. A synthetic medium, replicating concentrations of ammonia, $\mathrm{P}$ and carbon typical of municipal wastewater influent was used as an influent. Dissolved oxygen (DO) concentrations, volume exchange ratio, and biomass wasting were carefully managed to promote the growth of granular biomass. The performance of the reactor was closely monitored in terms of aerobic / anoxic $\mathrm{P}, \mathrm{N}$ removal, anaerobic $\mathrm{P}$ release and microbial community changes.

\section{Materials and methods}

\subsection{Sequencing batch reactor operation}

A laboratory-scale SBR reactor with a working volume of $4 \mathrm{~L}$ was operated at room temperature $\left(20-22^{\circ} \mathrm{C}\right)$ under alternating anaerobic/ aerobic conditions (Fig. 1). The reactor was seeded with waste activated sludge (WAS, 2 L) collected from a local municipal wastewater treatment plant (Subiaco, WA, Australia). The inoculum had a mixed liquor suspended solids (MLSS) concentration of approximately $4.0 \mathrm{~g} / \mathrm{L}$. The operational cycle included a $2 \mathrm{~h}$ anaerobic period with 5 min of feeding (synthetic medium), $2 \mathrm{~h}$ of aerobic period, 20 min settling and 10 min decanting. Sodium salts of Acetate and propionate were alternately used (bi-weekly) as the carbon source to facilitate the enrichment of PAOs (Lu et al., 2006). At the beginning of the anaerobic phase, 2.8 litres of synthetic wastewater was pumped into the reactor, enabling a volume exchange ratio of $70 \%$, which was considered desirable for the enrichment of the granules. The hydraulic retention time (HRT) and solid retention time (SRT) 
were maintained at $9 \mathrm{~h}$ and 20 days, respectively. The reactor was operated for a period of 110 days.

National Instrument hardware (CompactRIO) and software (Labview) were used to control, monitor and automate the operation of the reactor. Mixing was achieved at $50 \mathrm{rpm}$ using an overhead stirrer (RZR2020, Heidolph, Germany). Maintenance of DO at set point was achieved using a luminescent $\mathrm{DO}$ probe $\left(\mathrm{PDO}_{2}\right.$; Barben Analyser Technology, USA) and the Labview software by switching on and off a solenoid valve connected to a compressed air outlet. The DO level was maintained between 0.30 and $0.8 \mathrm{mg} / \mathrm{L}$. An intermediate junction $\mathrm{pH}$ sensor (Ionode IJ44, Ionode Pty Ltd, Australia) and an intermediate junction redox sensor (Ionode IJ64, Ionode Pty Ltd, Australia) were also fitted into the reactor and their outputs were recorded online. The $\mathrm{pH}$ in the reactor was not controlled.

\subsection{Synthetic medium}

The 2.8 L synthetic feed was composed of $40 \mathrm{~mL}$ of solution A, $200 \mathrm{~mL}$ of solution B, $200 \mathrm{~mL}$ of solution $\mathrm{C}$ and $2.36 \mathrm{~L}$ of deionised water. The composition of these three stock solutions were as follows: Stock solution A (per L): $25.63 \mathrm{~g} \mathrm{CH}_{3} \mathrm{COONa}$ or $17.15 \mathrm{~g} \mathrm{CH}_{3} \mathrm{CH}_{2} \mathrm{COONa}$; Stock solution B (per L): $0.9 \mathrm{~g} \mathrm{MgSO}_{4}, 3.05 \mathrm{~g} \mathrm{NH}_{4} \mathrm{Cl}, 7.5 \mathrm{mg}$ Peptone, $7.5 \mathrm{mg}$ Yeast extract, $142.5 \mathrm{mg} \mathrm{CaCl} 2.2 \mathrm{H}_{2} \mathrm{O}, 30 \mathrm{mg}$ ethylenediaminetetraacetic acid (EDTA), $4.5 \mathrm{mg} \mathrm{FeCl} 3.6 \mathrm{H}_{2} \mathrm{O}$, $0.36 \mathrm{mg} \mathrm{ZnSO} 4.7 \mathrm{H}_{2} \mathrm{O}, 0.36 \mathrm{mg} \mathrm{MnCl} 2.4 \mathrm{H}_{2} \mathrm{O}, 0.18 \mathrm{mg} \mathrm{Na}_{2} \mathrm{MoO}_{4} .2 \mathrm{H}_{2} \mathrm{O}, 0.09 \mathrm{mg} \mathrm{CuSO}{ }_{4} .5 \mathrm{H}_{2} \mathrm{O}$, $0.45 \mathrm{mg} \mathrm{CoCl} 2.6 \mathrm{H}_{2} \mathrm{O}, 0.54 \mathrm{mg} \mathrm{KI}, 0.45 \mathrm{mg} \mathrm{H} \mathrm{H}_{3} \mathrm{BO}_{3}$; Stock solution C (per L): $0.37 \mathrm{~g} \mathrm{KH}_{2} \mathrm{PO}_{4}$, $0.65 \mathrm{~g} \mathrm{~K}_{2} \mathrm{HPO}_{4}$. The introduction of the feed at the beginning of the cycle, imposed a $\mathrm{PO}_{4}{ }^{3}-\mathrm{P}$ concentration of $10 \mathrm{mg} / \mathrm{L}$, an $\mathrm{NH}_{4}-\mathrm{N}$ concentration of $40 \mathrm{mg} / \mathrm{L}$ and a COD concentration of $200 \mathrm{mg} / \mathrm{L}$ in the reactor. 
169

1 2 3 4

\subsection{Process monitoring and chemical analysis}

170 Long-term performance monitoring of the reactor was carried out with routine influent and 171 effluent sampling and mixed liquor suspended solids (MLSS) measurements. Influent and 172 effluent samples were immediately filtered using $0.22 \mu \mathrm{m}$ pore size syringe filters (Cat. No. 173 SLGN033NK, Merck Pty Ltd, Australia) and stored at $4^{\circ} \mathrm{C}$. The concentration of MLSS in the 174 reactor was determined according to Standard Methods for the Examination of Water and 175 Wastewater (Rice et al., 2012).

176 The reactor performance was monitored by conducting cyclic studies. The cyclic studies 177 facilitated the monitoring of $\mathrm{N}$ removal and $\mathrm{P}$ uptake/release kinetics of the biomass. Each cyclic study involved withdrawing $2 \mathrm{ml}$ of sample from the reactor every $15-30 \mathrm{~min}$ over the entire 6-h cycle. Each sample was immediately filtered using a $0.22 \mu \mathrm{m}$ pore size syringe filter (Cat. No. SLGN033NK, Merck Pty Ltd, Australia). At the end of each cyclic study the MLSS of the reactor was determined in accordance to the Standard Methods for the Examination of Water and Wastewater (Rice et al., 2012). Additionally, $2 \mathrm{ml}$ volumes of settled biomass was also collected (on 7, 23, 34, 62, 90 and $110 \mathrm{~d}$ of reactor operation) for microbial analysis.

The $\mathrm{PO}_{4}{ }^{3-}-\mathrm{P}, \mathrm{NH}_{4}{ }^{+}-\mathrm{N}, \mathrm{NO}_{3}{ }^{-}-\mathrm{N}, \mathrm{NO}_{2}{ }^{-}-\mathrm{N}, \mathrm{Mg}^{2+}$ and acetate concentrations in the filtered samples were determined using ion chromatography (ICS-3000, DIONEX). A Dionex ICS-3000 reagent free ion chromatography (RFIC) system equipped with an IonPac ${ }^{\circledR}$ AS18 4 x 250 mm column was used to measure acetate, nitrite and nitrate concentrations in liquid samples. Potassium hydroxide was used as an eluent at a flow rate of $1 \mathrm{~mL} / \mathrm{min}$. The potassium hydroxide concentration was 12-45 $\mathrm{mM}$ from 0-5 $\mathrm{min}, 45 \mathrm{mM}$ from 5-8 $\mathrm{min}, 45-60 \mathrm{mM}$ from 8-10 min and 60-12 mM from 10-13 min. Ammonium $\left(\mathrm{NH}_{4}{ }^{+}-\mathrm{N}\right)$ and $\mathrm{Mg}^{2+}$ were measured with the same RFIC but with a IonPac ${ }^{\circledR}$ CG16, CS16, $5 \mathrm{~mm}$ column. Methansulfonic acid was used as the eluent at a flow rate of $1 \mathrm{~mL} / \mathrm{min}$ and a $30 \mathrm{mM}$ concentration was maintained for $29 \mathrm{~min}$. 
The temperature of the two columns were maintained at $30^{\circ} \mathrm{C}$. Suppressed conductivity was used as the detection signal (ASRS ULTRA II $4 \mathrm{~mm}, 150 \mathrm{~mA}$, AutoSuppression ${ }^{\circledR}$ recycle mode).

\subsection{Microbiological analysis}

198 Biomass samples were taken from the reactor for microbiological analysis. Upon collection, 199 the biomass samples were immediately stored in a $-80{ }^{\circ} \mathrm{C}$ freezer. Subsequently, the samples 200 were thawed at room temperature in preparation to extract DNA for 454 pyrosequencing. DNA 201 extractions were carried out using the PowerSoil ${ }^{\circledR}$ DNA Isolation Kit (MO BIO Laboratories, 202 Inc., USA) and stored at $-20^{\circ} \mathrm{C}$ until sequenced. DNA sequencing was carried out as previously 203 described (Nagel et al., 2016).

204 In brief, the extracted DNA was quantified using a Qubit fluorometer, and 1-ng samples were 205 amplified using the $16 \mathrm{~S}$ ribosomal ribonucleic acid (rRNA) gene V4/5 primers (515F: 206 GTGCCAGCMGCCGCGGTAA and 806R: GGACTACHVGGGTWTCTAAT) (Caporaso et 207 al., 2010). Specifically, the above gene-specific primers were used with gene-specific primers 208 tagged with Ion Torrent-specific sequencing adaptors and barcodes. The tagged and untagged 209 primers were mixed at a ratio of 90:10. Amplification of all samples were restricted to 18-20 210 cycles minimising primer-dimer formation. Amplification was confirmed by agarose gel 211 electrophoresis, and amplified products were quantified by fluorometry. Subsequently up to 212100 amplicons were diluted to equal concentrations and adjusted to a final concentration of 60 213 pM. Templated Ion Sphere Particles (ISP) were then generated and loaded onto sequencing 214 chips using an Ion Chef (Thermofisher Scientific) and sequenced on a PGM semiconductor 215 sequencer (Thermofisher Scientific) for 650 cycles using a 400 bp sequencing kit that yields a 
modal read length of 309 bp. Data collection and read trimming/filtering was performed using

\section{TorrentSuite 5.0.}

\subsection{Bioinformatics Pipeline}

The Quantitative Insights into Microbial Ecology (QIIME) software package version 1.9.1 221 (Caporaso et al., 2010) was used for processing of the sequenced data. Three main files (454222 machine generated FASTA file \& quality score file and user generated mapping file) were used 223 for downstream analysis in QIIME. The split_libraries.py script was used to separate reads in 224 the FASTA file according to the mapping file. Chimeric sequence reads were thereafter 225 identified and filtered using USEARCH61 and an unaligned reference SILVA database 226 (Version 128) 97_otus_16S.fasta (Quast et al., 2013). Subsequently, operational taxonomic 227 units (OTUs) were assigned at $97 \%$ sequence similarity using the same reference database file 228 from SILVA. Once a representative sequence was appointed for each OTU picked, a taxonomic

\section{Results and discussion}

\subsection{The reactor successfully established a stable biomass with good $P$ uptake/release and $N$} removal

236 Upon inoculation with activated sludge, approximately 3 months was required to develop a 237 granular biomass that satisfactorily maintained low $\mathrm{N}, \mathrm{P}$ and $\mathrm{C}(0 \mathrm{mg} \mathrm{NH} 4-\mathrm{N} / \mathrm{L}, 0.8 \mathrm{mg} \mathrm{NOx}-$ $238 \mathrm{~N} / \mathrm{L}, 0 \mathrm{mg} \mathrm{PO}{ }^{3-}-\mathrm{P} / \mathrm{L}$ and $0 \mathrm{mg}$ acetate/L) concentrations in the effluent. During the first 62 
days, there was an attempt to maintain a DO level ranging from 0.4 to $0.6 \mathrm{mg} / \mathrm{L}$ in the aerobic period. However, the system failed to maintain the desired DO set point as over $2 / 3$ of the cycle, the DO fluctuated between 0 and $0.4 \mathrm{mg} / \mathrm{L}$ (Fig. 3a). Nonetheless, this mode of operation still enabled a rapid improvement in the aerobic $\mathrm{P}$ uptake and anaerobic P release activity of the biomass. Specifically, both aerobic $\mathrm{P}$ uptake and anaerobic P release activities increased almost identically (approximately 2 to $20 \mathrm{mg} \mathrm{PO}_{4}^{-3}-\mathrm{P} / \mathrm{g}-\mathrm{MLSS}$ ) during the period of $0-62$ days (Fig. 2a). This also coincided with an increase in both nitrification and denitrification activities. However, compared to the increase of aerobic $\mathrm{P}$ uptake and anaerobic P release activities, the increase of nitrification and denitrification activities were approximately 6 times lower (Fig. 2a). The MLSS only marginally fluctuated $(4.18 \pm 0.62 \mathrm{~g} / \mathrm{L})$ throughout the entire period of reactor operation (Fig. 2a) suggesting only a minor change in biomass concentration in the reactor. Since the amount of suspended solids in the synthetic feed was negligible, the values of MLSS were considered as close estimates of the biomass concentration in the reactor.

The steady MLSS observed throughout reactor operation is a result of the high-volume exchange ratio (70 \%) and SRT (20 d) maintained.

254 The results obtained thus far suggested that the increased nutrient removal was likely a result of an increase in either the abundance or the enzymatic activities of specific microbial communities. In fact, along with the increase of biological activity, the specific release and uptake rates of $\mathrm{P}$ also increased in the reactor (Fig. 2b). However, an increasing difference was noted between specific P release and uptake rates (Fig. 2b). The low specific P uptake rate, necessitated a prolonged exposure of biomass to aerobic conditions to enable a complete removal of P. Similarly, during the first 62 days, although nitrification and denitrification 261 activities increased, specific nitrification and denitrification rates declined or remained 262 analogous to day 7 (Fig. 2c). The low specific P uptake and the nitrification rates were most likely a result of the low DO concentration that prevailed during the aerobic period of the 
reactor. Hence, from day 62 onwards, the DO set point of the reactor was increased to maintain a DO concentration of $0.3-0.6 \mathrm{mg} / \mathrm{L}$ throughout the aerobic period. This resulted in a gradual increase of specific P uptake rate (Fig. 2b). The increase of DO also enriched the PAOs (i.e. both aerobic and DPAOs) and by day 110, the overall PAO abundance reached $12 \%$ (Fig. 2d). The increase of PAOs and DO facilitated similar specific P release / uptake rates (i.e. 24.14 and $23.52 \mathrm{mg}-\mathrm{P} / \mathrm{g} . \mathrm{MLSS}$.h respectively) and this enabled a rapid removal of $\mathrm{P}$ during the aerobic/anoxic period of the reactor cycle.

The increase of DO also increased the specific nitrification and denitrification rates, which were 2.41 and $2.46 \mathrm{mg}-\mathrm{N} / \mathrm{g}$.MLSS.h respectively by day 110 (Fig. 2c). A marginal increase of the ammonia oxidising bacteria ( $\mathrm{AOB}$ ) and the nitrite oxidising bacteria (NOB) population was also observed once the DO concentration was increased in the reactor (Fig. 2e). The increase of denitrification rate correlated with an increase of DPAO and DGAO abundance in the reactor, suggesting that DPAOs and/or DGAOs were responsible for the observed increase of denitrification. An overall decrease in abundance of order Burkholderiales (a bacterial order known to contain denitrifiers (Thomsen et al., 2007)) from 22.5 to $7.25 \%$ between days 34 and 110 (Fig. 2f) suggest a possible decrease in abundance of heterotrophic denitrifiers. The marginal increase of abundance and/or community shift of the order Rhodocyclales (a bacterial order known to contain DPAOs and DGAOs (Zhang et al., 2018)), on the other hand coincided with an increase of DPAOs and/or DGAOs in the reactor. Overall, the increase of nitrification, denitrification and P removal resulted in a low nutrient content in the reactor effluent.

\subsection{The change of microbial composition influenced the reactor performance}

286 Fig. $2 \mathrm{f}$ illustrates a large microbial community shift in the reactor between 7 and 34 days of 287 operation. There was a gradual reduction in the relative abundance of the members of order 
Rhodocyclales, which consists of microorganisms such as Candidatus Accumulibacter (a wellknown PAO), Propionivibrio (a well-known GAO), Thauera, Dechloromonas and Sulfuritalea (which are known denitrifiers/aerobic heterotrophs) (Coyotzi Alcaraz, 2014; Lu et al., 2006; McIlroy et al., 21 - 26 Aug 2016). The relative abundance of glycogen accumulating organisms (GAOs) and other heterotrophs decreased and the relative abundance and / or activity of PAOs increased during this period (Fig. 2d). The result also corroborated with the rapid increase of P uptake/release activity recorded during this period (Fig. 2a).

295 On the other hand, the decrease in the relative abundance of the members of order 296 Rhodocyclales coincided with an increase in abundance of the members of order 297 Burkholderiales (Fig. 2f). Bacterial genera such as Rhodoferax and Acidovorax of 298 Burkholderiales are known for their ability to denitrify (Thomsen et al., 2007). Hence, the

\subsection{The PAOs had a higher affinity towards oxygen}

Two cyclic studies carried out on days 62 and 110 were compared to understand how an increase of DO would impact the overall performance of the reactor. The cyclic study carried out on day 62 (Fig. 3a) revealed a poor removal of $\mathrm{NH}_{4}{ }^{+}-\mathrm{N}$. In this cyclic study, a clear bending point was recorded in the $\mathrm{NH}_{4}{ }^{+}-\mathrm{N}$ profile during the aerobic phase of the reactor cycle (Fig. 3a). During the initial $2 \mathrm{~h}$ of the aerobic cycle, the $\mathrm{NH}_{4}{ }^{+}-\mathrm{N}$ removal rate was $0.7 \mathrm{mg} / \mathrm{g}-\mathrm{MLSS} . \mathrm{h}$. After 2 hours into the aerobic cycle, $\mathrm{P}$ was completely up taken by the PAOs and thereafter a 
312

313

314

315

316

11

12

higher $\mathrm{NH}_{4}{ }^{+}-\mathrm{N}$ removal rate of $1.35 \mathrm{mg} / \mathrm{g}$-MLSS.h was observed (Fig. 3a). Although the reactor was aerated during the entire aerobic phase, there was no measurable concentration of DO during the first $30 \mathrm{~min}$ of reactor operation (Fig. 3a). During this period, the removal of $\mathrm{NH}_{4}{ }^{+}-\mathrm{N}$ was insignificant when compared with the removal of $\mathrm{PO}_{4}{ }^{3-}-\mathrm{P}$ (Fig. 3a). This suggests that biological ammonia oxidation (driven by $\mathrm{AOB}$ ) was compromised during this period, and PAOs appeared to have preferentially utilised all of the supplied oxygen to uptake P. An increase of $\mathrm{DO}$ in the reactor was only noted once $\mathrm{PO}_{4}{ }^{3-}-\mathrm{P}$ concentration decreased to approximately below $40 \mathrm{mg} / \mathrm{L}$ and this coincided with an increased AOB activity as reflected by the increased removal of $\mathrm{NH}_{4}^{+}-\mathrm{N}$.

The above observation implies that the acclimatised PAOs in the biomass had a higher affinity towards oxygen when compared with AOBs. Blackburne et al. (2008) however, showed that AOBs have a higher affinity towards oxygen in a study that was conducted to examine whether NOBs could be washed out in a continuous-flow reactor using DO concentration as the only selection factor. Similarly, Carvalheira et al. (2014) showed that PAOs also have a higher affinity towards oxygen in a study they carried out to examine the impact of aeration on PAOs and GAOs. Although both AOBs and PAOs are known to have higher affinities towards oxygen, to our knowledge no study has examined which of these two has the highest affinity towards oxygen in a single study. The findings of this study complement the findings of Yang et al. (2016) and provides indirect evidence that PAOs have a higher affinity towards oxygen compared to AOBs. Based on independent studies of Carvalheira et al. (2014) and Rongsayamanont et al. (2010), Yang et al. (2016) suggests that PAOs have a higher affinity towards oxygen when compared with AOBs. However, to be conclusive and comparative, the oxygen Monod half saturation constants $\left(K_{o}\right)$, for both AOBs and PAOs should be determined against a single SNDPR sludge. 


\subsection{Dissolved oxygen (DO) concentration of $0.5 \mathrm{mg} / \mathrm{L}$ was essential to achieve complete} nutrient removal and a high $P$ concentration at the end of the anaerobic phase

Increasing the DO concentration in the reactor increased the availability of oxygen for both $\mathrm{P}$ uptake and nitrification to simultaneously occur from the start of the aerobic phase of the reactor cycle (Fig. 3b). An unchanged rate of $\mathrm{NH}_{4}{ }^{+}-\mathrm{N}$ reduction before and after completion of $\mathrm{P}$ uptake, suggests that nitrification occurred at its maximum rate during the entire aerobic period, implying that AOBs were not limited by oxygen. While the bulk of the NOx-N produced from nitrification was simultaneously removed, a small concentration was observed accumulating in the reactor (Fig. 3b). This small increase of NOx-N confirms that the denitrification rate was marginally lower than the nitrification rate in this reactor. Since the nitrification process was completed approximately $30 \mathrm{~min}$ prior to the end of the cycle, the remaining $30 \mathrm{~min}$ of the cycle was sufficient to completely remove $\mathrm{NOx}-\mathrm{N}$ from the final effluent.

Maintaining a suitable oxygen gradient within the granule is essential for the described SNDPR process to occur. In this study, a DO concentration of approximately $0.5 \mathrm{mg} / \mathrm{L}$ (during the aerobic phase) was found to be suitable to achieve a similar nitrification and a denitrification

rate. The bulk water DO concentration enabled both oxygen-demanding (i.e. P uptake by PAOs and nitrification by $\mathrm{AOB}$ ) and denitrification reactions to simultaneously take place, enabling an efficient SNDPR process. The results further revealed that an increase in DO concentration to approximately $0.5 \mathrm{mg} / \mathrm{L}$ (due to a completion of $\mathrm{P}$ uptake), was not detrimental for a complete removal of $\mathrm{N}$. This finding is noteworthy because DO concentrations in excess of 0.5 $\mathrm{mg} / \mathrm{L}$ have been demonstrated as detrimental to the SNDPR process (Meyer et al., 2005). Specifically, elevated levels of DO were thought to further oxidise nitrite $\left(\mathrm{NO}_{2}^{-}-\mathrm{N}\right)$ into nitrate $360\left(\mathrm{NO}_{3}{ }^{-}-\mathrm{N}\right)$, increasing carbon requirements to remove $\mathrm{P}$ and $\mathrm{NO}_{\mathrm{x}}{ }^{-}-\mathrm{N}$ from the final effluent 361 (Meyer et al., 2005; Zeng et al., 2004). 


\subsection{A low COD:N ratio similar to that of municipal wastewater can facilitate a high}

concentration of $P$ release, enabling $P$ recovery

365 The influent used in this study had $\mathrm{C}$ and $\mathrm{N}$ contents similar to that of a typical municipal wastewater, as characterised by a low COD:N ratio (here approximately five). To determine whether the SNDPR process had become more efficient at releasing P during the anaerobic phase, the specific P release rates were calculated (Fig. 2b). Clearly, the rate of $\mathrm{P}$ release during the anaerobic phase of the process increased gradually over the entire period of the study, reaching a maximal rate of $24 \mathrm{mg} / \mathrm{g}$.MLSS.h at day 110 (Fig. 2b). Further, during the initial days of reactor operation, the COD: $\mathrm{P}_{\text {released }}$ ratio was high, approximately 25 (at day 7). However, a more than 10-fold decrease of this ratio was achieved after 110 days of operation (to 2.35), signifying that the biomass became more efficient in using the influent carbon to facilitate $\mathrm{P}$ release (Fig. $3 \mathrm{a} \& \mathrm{~b}$ ). Upon achieving this low COD: $\mathrm{P}_{\text {released }}$ ratio, the $\mathrm{PO}_{4}{ }^{3-}-\mathrm{P}$ concentration increased to $100 \mathrm{mg} / \mathrm{L}$ at the end of the anaerobic phase of the cycle (Fig. $3 \mathrm{a} \&$ b). Given that the influent $\mathrm{PO}_{4}{ }^{3-}-\mathrm{P}$ concentration was low $(10 \mathrm{mg} / \mathrm{L})$, the ability of the described process to increase the $\mathrm{PO}_{4}{ }^{3-}-\mathrm{P}$ concentration by 10 -fold (i.e. reaching $\sim 100 \mathrm{mg} \mathrm{P} / \mathrm{L}$ at end of the anaerobic phase) creates an opportunity to recover influent $\mathrm{PO}_{4}{ }^{3-}-\mathrm{P}$ in a smaller volume as a concentrated $\mathrm{PO}_{4}{ }^{3-}-\mathrm{P}$ liquor.

To our knowledge, this is the first study to demonstrate that a high concentration of $\mathrm{PO}_{4}{ }^{3-}-\mathrm{P}$ (up to $100 \mathrm{mg}-\mathrm{P} / \mathrm{L}$ ) can be achieved in a SNDPR process using a wastewater influent with a low COD/N ratio of five (COD concentration of $200 \mathrm{mg} / \mathrm{L}$ and an $\mathrm{NH}_{4}{ }^{+}-\mathrm{N}$ concentration of 40 $\mathrm{mg} / \mathrm{L})$ (Table 1). This is a notable finding, as earlier studies with similar low COD/N ratios have only demonstrated a low $\mathrm{PO}_{4}{ }^{3-}-\mathrm{P}$ release of approximately $\sim 40 \mathrm{mg} / \mathrm{L}$ (Wang et al., 2015; Wang et al., 2016b) (Table 1). Given that municipal wastewater typically contains only low 
concentrations of biodegradable COD, the results of this study highlight the potential of using SNDPR to promote $\mathrm{P}$ recovery while achieving excellent removal of nutrients and $\mathrm{C}$ from municipal wastewater. Nonetheless, further studies using real municipal wastewater as influent are required to validate the current findings.

\subsection{Are DGAOs primarily responsible for denitrification?}

In the SNDPR process, organic carbon is introduced into the reactor during the anaerobic phase of the cycle. In this study, the organic carbon (acetate or propionate) in the synthetic wastewater was fully consumed and stored by the granular biomass (Fig. 3) in the complete absence of any electron acceptor. Hence, PAOs, DPAOs, GAOs and/or DGAOs are the likely organisms that stored majority of the COD that prevailed in the influent.

The observed denitrification in the described process took place both during and after $\mathrm{P}$ uptake was completed (Fig 3). In the absence of $\mathrm{P}$ and a source of carbon, denitrification could only take place with the assistance of DGAOs, whereas denitrification during P uptake may have been a result of both DPAOs and DGAOs. Fig 4 shows a gradual increase in the denitrification rates before and after $\mathrm{P}$ exhaustion (i.e. in the presence and absence of $\mathrm{P}$ ) during the acclimatisation period in the reactor. During the early operation of the reactor (i.e. $62 \mathrm{~d}$ ), the denitrification rates observed in the presence of $\mathrm{P}$ were an order of magnitude higher compared to the denitrification rates observed in the absence of P (Fig. 4). According to the cyclic study on day 62 (Fig. 3a), the accumulation of NOx-N specifically after exhaustion of $\mathrm{P}$, was a result of the low denitrification rate and/or a higher nitrification rate. The nitrification rate, however, only increased marginally ( $0.2 \mathrm{mg} / \mathrm{L} . \mathrm{h})$ after exhaustion of $\mathrm{P}$ (Fig. 3a) and hence, the accumulation of NOx-N resulted from the reduction of the denitrification rate. This suggests that in addition to DGAOs, DPAOs were also likely to be contributing towards denitrification 
410

411

when $\mathrm{P}$ was present in the reactor. The reduced denitrification rate observed in the absence of $\mathrm{P}$ (i.e. after all the $\mathrm{PO}_{4}{ }^{3-}-\mathrm{P}$ was up taken by PAOs or DPAOs) was most likely due to the inability of DPAOs to denitrify and this also suggests DPAOs reliance on $P$ to remain active in the reactor (Fig. 4). During the final days of reactor operation, the denitrification rates observed in the absence of $\mathrm{P}$ far exceeded denitrification rates observed in the presence of $\mathrm{P}$ (Fig. 4). This is a result of an increased DGAO activity and/or an increased DGAO abundance. A microbial analysis confirmed an increase of DGAO abundance from approximately 1.2 to 4.5 $\%$ between 62 and 110 days of reactor operation. Although chemical data does not suggest an increase or a decrease of DPAO activity, the microbial analysis indicated a $1.5 \%$ reduction in the abundance of DPAOs during the final 20 days of reactor operation. This $1.5 \%$ decline in DPAO abundance coincided with a $1.3 \%$ increase of DGAO abundance and this overall facilitated a bacterial community that enabled complete removal of N, P and C from the influent wastewater.

4. Conclusions

425 This study examined whether a SNDPR process could facilitate recovery of $\mathrm{P}$ as a concentrated 426 liquor at the end of the anaerobic phase of the reactor cycle. Based on the results the following 427 can be concluded.

- $\quad \mathrm{A} \mathrm{PO}_{4}{ }^{3-}-\mathrm{P}$ concentration as high as $100 \mathrm{mg} / \mathrm{L}$ is achievable at the end of the anaerobic phase of the reactor cycle. This concentrated stream of $\mathrm{PO}_{4}{ }^{3-}-\mathrm{P}$ enabled recovery of influent $\mathrm{PO}_{4}{ }^{3-}-\mathrm{P}(10 \mathrm{mg} / \mathrm{L})$ in a very small volume as a concentrated liquor and enables economies of scale to recover P specifically as struvite (Adnan et al., 2003).

- A COD concentration of $200 \mathrm{mg} / \mathrm{L}$ is adequate to create a concentrated stream of $\mathrm{PO}_{4}{ }^{3-}$ -P suitable for $\mathrm{P}$ recovery at the end of the anaerobic phase of the reactor cycle. The 
use of COD to create such a high concentrated stream of P did not hinder effective removal of NOx-N. Specifically, C was not found to be a limiting factor for

\section{Acknowledgments}

446 This project was funded by CSIRO Land and Water. Curtin University is acknowledged for 447 the Curtin University Postgraduate Student Association (CUPSA) academic grant provided to 448 Sara Salehi Lashkajani. The authors also would like to thank Dr Anna Kaksonen, Dr Haylea 449 Miller and Ana Mesquita from CSIRO Land and Water for their valuable comments to the 450 manuscript.

\section{References}

453 Adnan, A., Mavinic, D.S., Koch, F.A., 2003. Pilot-scale study of phosphorus recovery through 454 struvite crystallization - examining the process feasibility. J. Environ. Eng. Sci. 2, 315-324.

455 Azizi, S., Valipour, A., Sithebe, T., 2013. Evaluation of different wastewater treatment 456 processes and development of a modified attached growth bioreactor as a decentralized 457 approach for small communities. Sci. World J., 8. 
458

459

460

461

462

11

Barat, R., Montoya, T., Borrás, L., Ferrer, J., Seco, A., 2008. Interactions between calcium precipitation and the polyphosphate-accumulating bacteria metabolism. Water Res. 42, 34153424.

Blackburne, R., Yuan, Z.G., Keller, J., 2008. Partial nitrification to nitrite using low dissolved oxygen concentration as the main selection factor. Biodegradation 19, 303-312.

Caporaso, J.G., Kuczynski, J., Stombaugh, J., Bittinger, K., Bushman, F.D., Costello, E.K., 464 Fierer, N., Pena, A.G., Goodrich, J.K., Gordon, J.I., Huttley, G.A., Kelley, S.T., Knights, D., 465 Koenig, J.E., Ley, R.E., Lozupone, C.A., McDonald, D., Muegge, B.D., Pirrung, M., Reeder, 466 J., Sevinsky, J.R., Tumbaugh, P.J., Walters, W.A., Widmann, J., Yatsunenko, T., Zaneveld, J., 467 Knight, R., 2010. QIIME allows analysis of high-throughput community sequencing data. Nat. 468 Meth. 7, 335-336.

469 Carvalheira, M., Oehmen, A., Carvalho, G., Eusebio, M., Reis, M.A.M., 2014. The impact of 470 aeration on the competition between polyphosphate accumulating organisms and glycogen 471 accumulating organisms. Water Res. 66, 296-307.

472 Chuang, S.H., Ouyang, C.F., Wang, Y.B., 1996. Kinetic competition between phosphorus 473 release and denitrification on sludge under anoxic condition. Water Res. 30, 2961-2968.

474 Cieslik, B., Konieczka, P., 2017. A review of phosphorus recovery methods at various steps of 475 wastewater treatment and sewage sludge management. The concept of "no solid waste 476 generation" and analytical methods. J. Cleaner Prod. 142, 1728-1740.

477 Cordell, D., Drangert, J.O., White, S., 2009. The story of phosphorus: Global food security and 478 food for thought. Global Environmental Change-Human and Policy Dimensions 19, 292-305. 479 Coyotzi Alcaraz, S.V., 2014. Bacterial diversity and denitrifier communities in arable soils. 480 UWSpace. 
481

482

483

484

485

11

Jia, W., Liang, S., Ngo, H.H., Guo, W., Zhang, J., Wang, R., Zou, Y., 2013a. Effect of phosphorus load on nutrients removal and N 2 O emission during low-oxygen simultaneous nitrification and denitrification process. Bioresour. Technol. 141, 123-130.

Jia, W., Liang, S., Zhang, J., Ngo, H.H., Guo, W., Yan, Y., Zou, Y., 2013b. Nitrous oxide emission in low-oxygen simultaneous nitrification and denitrification process: Sources and mechanisms. Bioresour. Technol. 136, 444-451.

Kapagiannidis, A.G., Zafiriadis, I., Aivasidis, A., 2013. Comparison between aerobic and anoxic metabolism of denitrifying-EBPR sludge: effect of biomass poly-hydroxyalkanoates content. New Biotechnol. 30, 227-237.

Lee, D.S., Jeon, C.O., Park, J.M., 2001. Biological nitrogen removal with enhanced phosphate uptake in a sequencing batch reactor using single sludge system. Water Res. 35, 3968-3976.

Lemaire, R., Meyer, R., Taske, A., Crocetti, G.R., Keller, J., Yuan, Z., 2006. Identifying causes for $\mathrm{N} 2 \mathrm{O}$ accumulation in a lab-scale sequencing batch reactor performing simultaneous nitrification, denitrification and phosphorus removal. J. Biotechnol. 122, 62-72.

Li, H., Chen, Y., Gu, G., 2008. The effect of propionic to acetic acid ratio on anaerobic-aerobic (low dissolved oxygen) biological phosphorus and nitrogen removal. Bioresour. Technol. 99, $4400-4407$.

498 Lu, H., Oehmen, A., Virdis, B., Keller, J., Yuan, Z., 2006. Obtaining highly enriched cultures 499 of Candidatus Accumulibacter phosphates through alternating carbon sources. Water Res. 40, $500 \quad 3838-3848$

501 Lu, Y.Z., Wang, H.F., Kotsopoulos, T.A., Zeng, R.J., 2016. Advanced phosphorus recovery 502 using a novel SBR system with granular sludge in simultaneous nitrification, denitrification 503 and phosphorus removal process. Appl. Microbiol. Biotechnol. 100, 4367-4374.

504 McIlroy, S.J., Albertsen, M., Stokholm-Bjerregaard, M., Karst, S.M., Nielsen, P.H., 21 - 26 505 Aug 2016. Metagenomics and in situ analyses reveal Propionivibrio spp. to be abundant GAO 
in biological wastewater treatment systems, 16th International Symposium on Microbial

507 Ecology, Palais des Congres de Montreal.

508 McIlroy, S.J., Saunders, A.M., Albertsen, M., Nierychlo, M., McIlroy, B., Hansen, A.A., Karst, 509 S.M., Nielsen, J.L., Nielsen, P.H., 2015. MiDAS: The field guide to the microbes of activated 510 sludge. Database 2015.

511 Meyer, R.L., Zeng, R.J., Giugliano, V., Blackall, L.L., 2005. Challenges for simultaneous 512 nitrification, denitrification, and phosphorus removal in microbial aggregates: Mass transfer 513 limitation and nitrous oxide production. FEMS Microbiol. Ecol. 52, 329-338.

514 Nagel, R., Traub, R.J., Allcock, R.J.N., Kwan, M.M.S., Bielefeldt-Ohmann, H., 2016. 515 Comparison of faecal microbiota in Blastocystis-positive and Blastocystis-negative irritable 516 bowel syndrome patients. Microbiome 4.

517 Quast, C., Pruesse, E., Yilmaz, P., Gerken, J., Schweer, T., Yarza, P., Peplies, J., Glöckner, 518 F.O., 2013. The SILVA ribosomal RNA gene database project: Improved data processing and 519 web-based tools. Nucleic Acids Res. 41, D590-D596.

520 Rice, E.W., Bridgewater, L., American Public Health Association., American Water Works 521 Association., Water Environment Federation., 2012. Standard methods for the examination of water and wastewater, 22nd 2012 / ed. American Public Health Association, Washington, D.C. 523 Rongsayamanont, C., Limpiyakorn, T., Law, B., Khan, E., 2010. Relationship between 524 respirometric activity and community of entrapped nitrifying bacteria: Implications for partial 525 nitrification. Enzyme. Microb. Technol. 46, 229-236.

526 Shu, L., Schneider, P., Jegatheesan, V., Johnson, J., 2006. An economic evaluation of 527 phosphorus recovery as struvite from digester supernatant. Bioresour. Technol. 97, 2211-2216. 528 Tarayre, C., De Clercq, L., Charlier, R., Michels, E., Meers, E., Camargo-Valero, M., Delvigne, 529 F., 2016. New perspectives for the design of sustainable bioprocesses for phosphorus recovery 530 from waste. Bioresour. Technol. 206, 264-274. 
531 Thomsen, T.R., Kong, Y., Nielsen, P.H., 2007. Ecophysiology of abundant denitrifying 532 bacteria in activated sludge. FEMS Microbiol. Ecol. 60, 370-382.

533 Wang, Q., Garrity, G.M., Tiedje, J.M., Cole, J.R., 2007. Naïve Bayesian classifier for rapid 534 assignment of rRNA sequences into the new bacterial taxonomy. Appl. Environ. Microbiol. $53573,5261-5267$.

536 Wang, Q., Jia, W., Zhang, J., Li, C., Yang, W., 2016a. Nutrients removal and nitrous oxide 537 emission during simultaneous nitrification, denitrification, and phosphorus removal process: 538 impact of temperature. Desalin. Water Treat. 57, 26187-26195.

539 Wang, X., Wang, S., Xue, T., Li, B., Dai, X., Peng, Y., 2015. Treating low carbon/nitrogen $540(\mathrm{C} / \mathrm{N})$ wastewater in simultaneous nitrification-endogenous denitrification and phosphorous 541 removal (SNDPR) systems by strengthening anaerobic intracellular carbon storage. Water Res. $54277,191-200$

543 Wang, X., Wang, S., Zhao, J., Dai, X., Li, B., Peng, Y., 2016b. A novel stoichiometries 544 methodology to quantify functional microorganisms in simultaneous (partial) nitrification545 endogenous denitrification and phosphorus removal (SNEDPR). Water Res. 95, 319-329.

546 Wong, P.Y., Cheng, K.Y., Kaksonen, A.H., Sutton, D.C., Ginige, M.P., 2013. A novel post 547 denitrification configuration for phosphorus recovery using polyphosphate accumulating 548 organisms. Water Res. 47, 6488-6495.

549 Yang, Q., Shen, N., Lee, Z.M.P., Xu, G.J., Cao, Y.S., Kwok, B., Lay, W., Liu, Y., Zhou, Y., 550 2016. Simultaneous nitrification, denitrification and phosphorus removal (SNDPR) in a full551 scale water reclamation plant located in warm climate. Water Sci. Technol. 74, 448-456.

552 Yuan, Z.G., Pratt, S., Batstone, D.J., 2012. Phosphorus recovery from wastewater through 553 microbial processes. Curr. Opin. Biotechnol. 23, 878-883. 
554 Zeng, R.J., Lemaire, R., Yuan, Z., Keller, J., 2003. Simultaneous nitrification, denitrification, 555 and phosphorus removal in a lab-scale sequencing batch reactor. Biotechnol. Bioeng. 84, 170556178.

557 Zeng, R.J., Yuan, Z., Keller, J., 2004. Improved understanding of the interactions and 558 complexities of biological nitrogen and phosphorus removal processes. Rev. Environ. Sci. 559 Biotechnol. 3, 265-272.

560 Zhang, M.J., Qiao, S., Shao, D.H., Jin, R.F., Zhou, J.T., 2018. Simultaneous nitrogen and 561 phosphorus removal by combined anammox and denitrifying phosphorus removal process. J. 562 Chem. Technol. Biotechnol. 93, 94-104. 


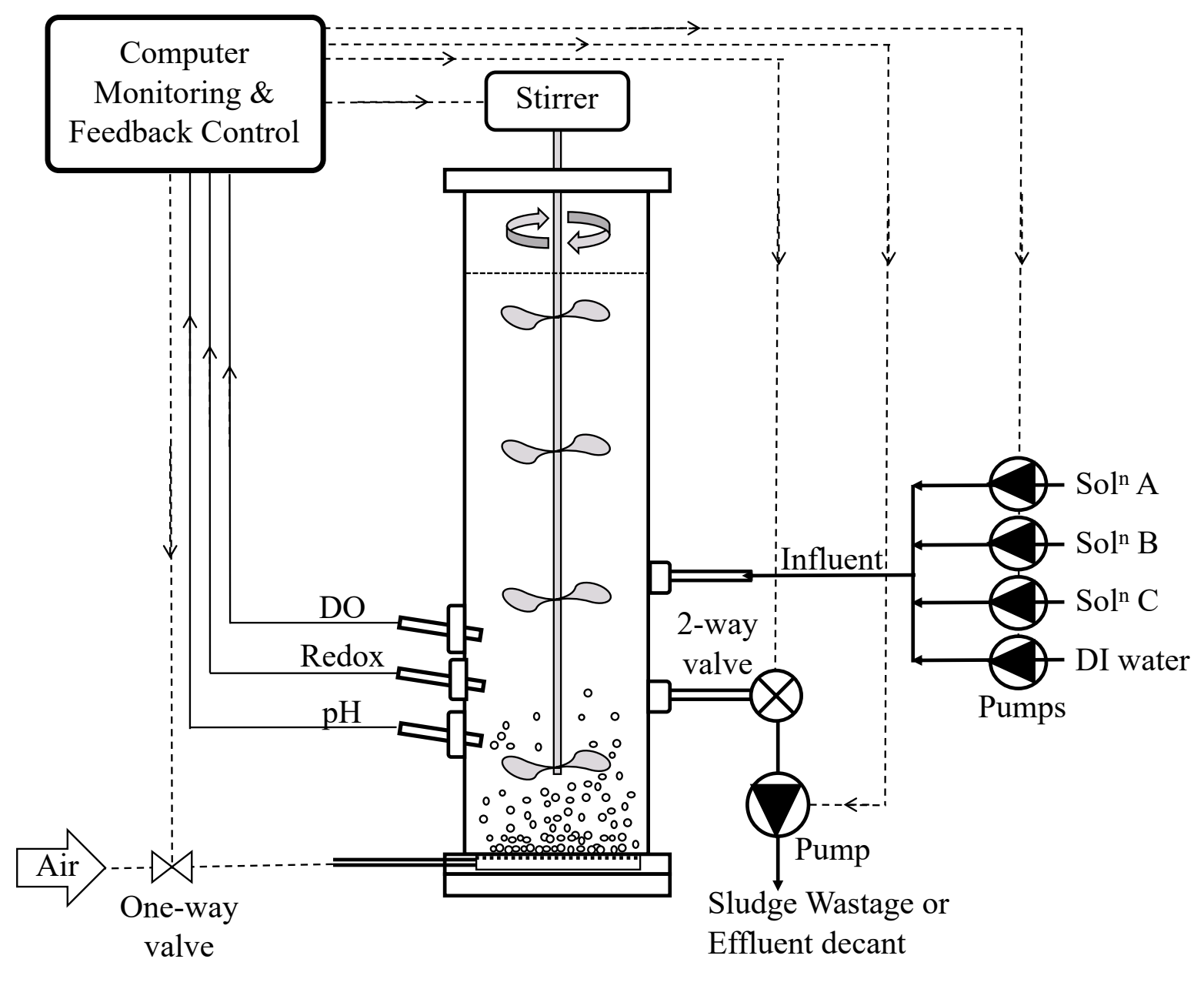

566 Fig. 1. Schematic of SBR reactor 

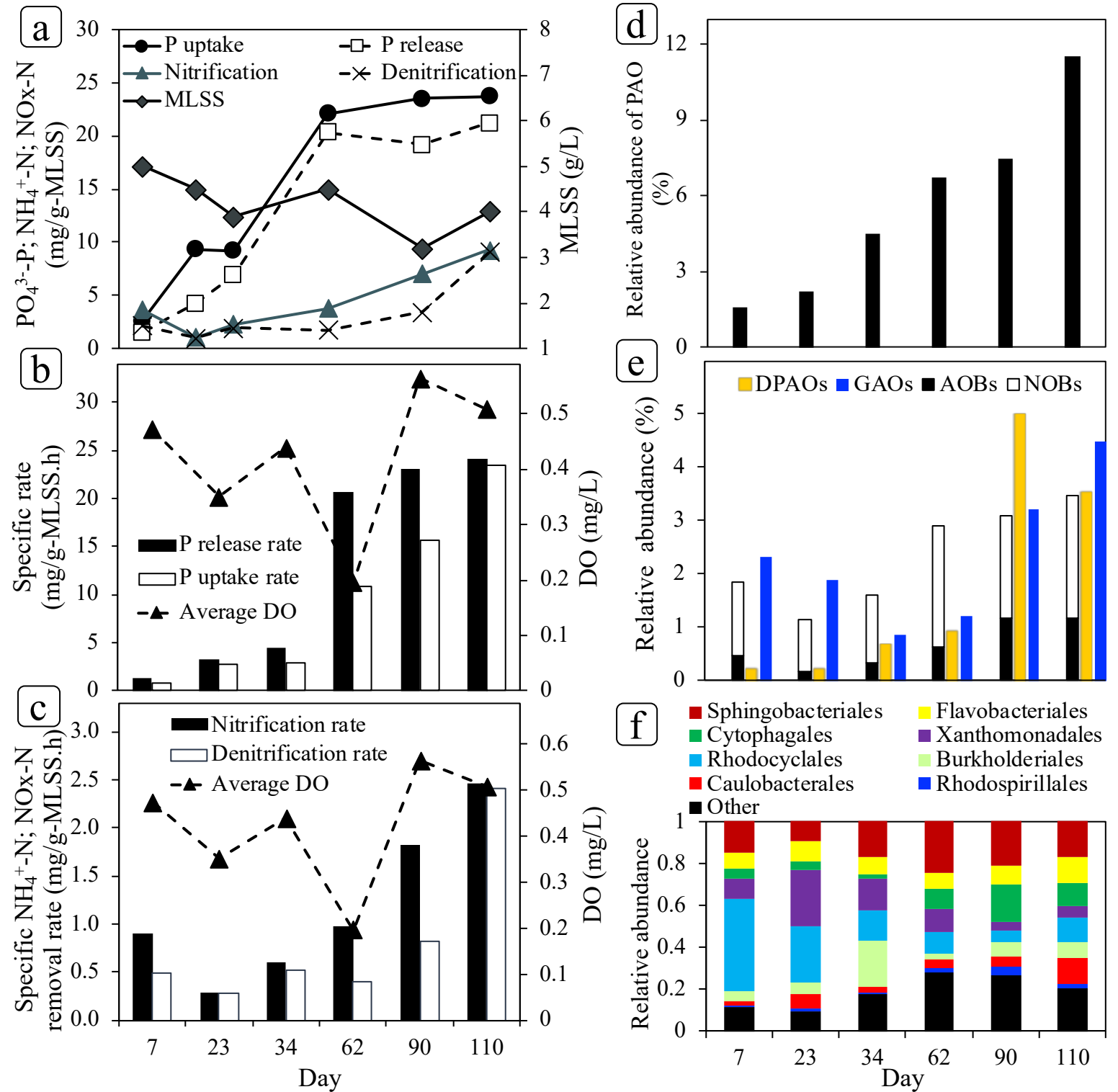

568 Fig. 2. (a) P uptake/release and nitrification/denitrification activity changes in the reactor; (b)

569 P uptake and release rates in the reactor; (c) Nitrification and denitrification rates in the reactor,

570 (d) The abundance and shift of bacteria classified to the order level; (e) Relative abundance of 571 PAOs; (f) Relative abundance of DPAOs, GAOs, AOBs, NOBs. 

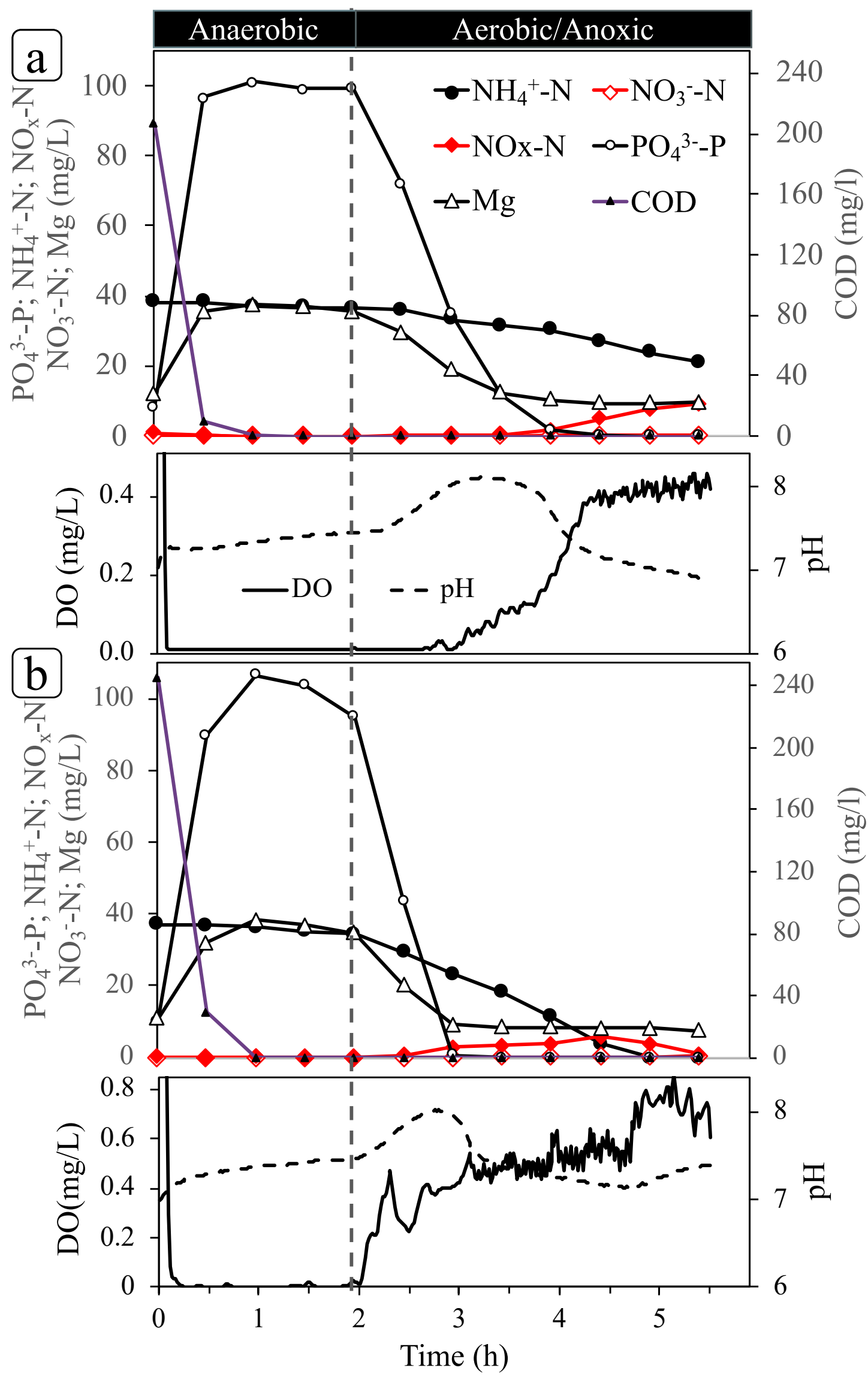

573 Fig. 3. Cyclic studies carried out on (a) $62 \mathrm{~d}$ and (b) $110 \mathrm{~d}$ 
1

2 3 4 5 6 7

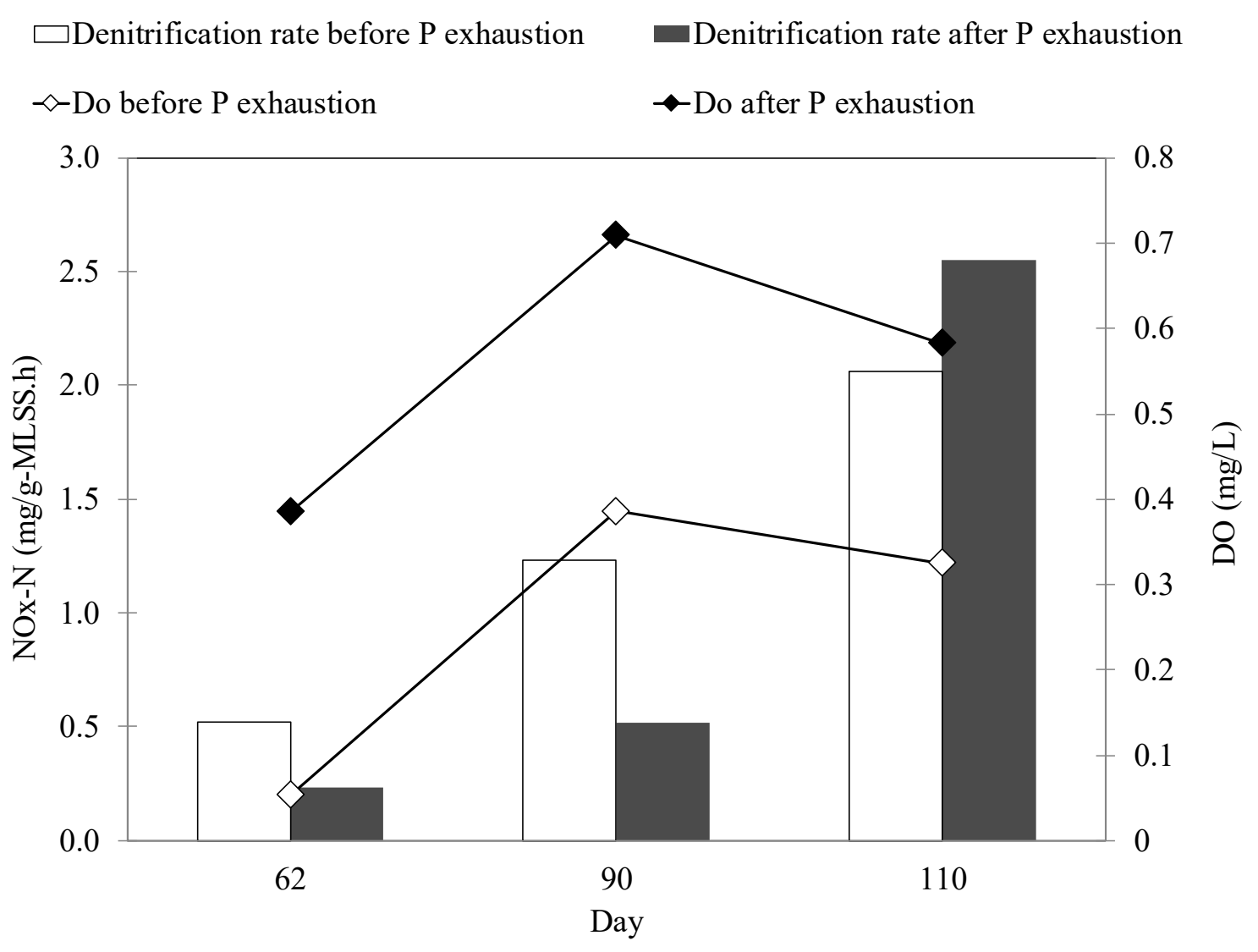

576 Fig. 4. Denitrification rates in the presence and absence of $P$ 
Table 1. A comparison of SNDPR studies

\begin{tabular}{|c|c|c|c|c|c|c|c|c|c|c|c|c|c|c|c|c|c|c|c|c|c|c|}
\hline & & & & & & & Operat & tional P & Parame & eters & & & & & $\begin{array}{l}\text { Wa } \\
\text { Char }\end{array}$ & $\begin{array}{l}\text { stewa } \\
\text { acteri }\end{array}$ & $\begin{array}{l}\text { ater } \\
\text { istics }\end{array}$ & & $\mathrm{P}$ & Perform & nance & \\
\hline Research & $\begin{array}{l}3 \\
e \\
0 \\
0 \\
00 \\
.0 \\
0 \\
0 \\
3 \\
3\end{array}$ & 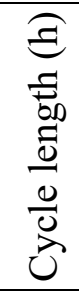 & 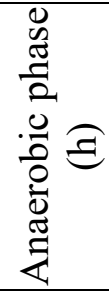 & $\begin{array}{l}0 \\
0 \\
\frac{0}{2} \\
0 \\
0 \\
0 \\
0 \\
0 \\
0 \\
0 \\
0\end{array}$ & 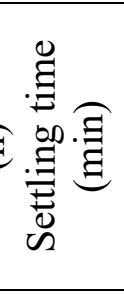 & 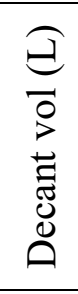 & 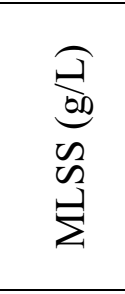 & 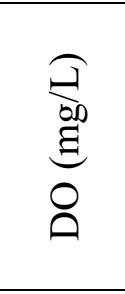 & 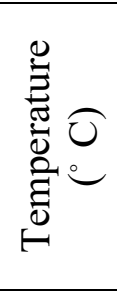 & 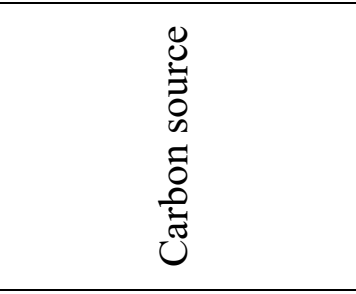 & 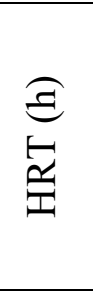 & 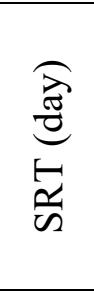 & ! & $\begin{array}{l}\overparen{J} \\
00 \\
\Xi \\
0 \\
0\end{array}$ & 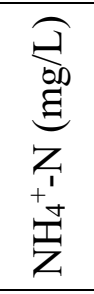 & 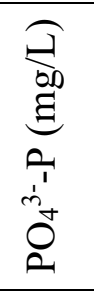 & $\frac{z}{0}$ & $\stackrel{\overbrace{}}{0}$ & 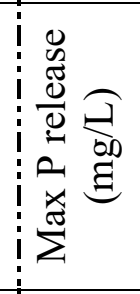 & 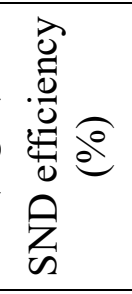 & 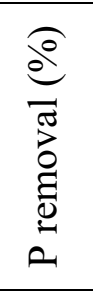 & 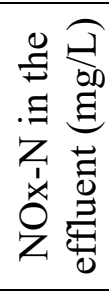 \\
\hline $\begin{array}{r}\text { (Lu et al., } \\
2016)\end{array}$ & 8 & 6.0 & 2.2 & 2.7 & 60 & 2.0 & $2.2-3.5$ & $0.8-1.6$ & 20 & $\mathrm{NaAc}$ & 24 & 8 & 7.5 & 800 & 50 & 36 & 16 & 22 & 75 & 57 & 100 & 3 \\
\hline $\begin{array}{r}\text { (Zeng et al., } \\
2003)\end{array}$ & 4 & 4.8 & 1.0 & 3.0 & 43 & 2.0 & 3.3 & $0.5-0.6$ & $18-22$ & $\mathrm{NaAc}$ & 9.6 & 15 & 7-7.5 & 400 & 40 & 15 & 10 & 27 & 75 & 98 & 100 & 0 \\
\hline $\begin{array}{r}\text { (Lemaire et al., } \\
2006)\end{array}$ & 5 & 6.0 & 1.5 & 3.6 & 40 & 3.0 & $3.9-4.6$ & $0.4-0.5$ & $20-22$ & $\mathrm{NaAc}$ & 10 & 20 & $7-7.5$ & 230 & 23 & 10 & 10 & 23 & 110 & & 100 & 0 \\
\hline $\begin{array}{r}\text { (Jia et al., } \\
\text { 2013a) }\end{array}$ & 5 & 6.0 & 1.5 & 3.0 & 70 & 3.0 & $3.0-3.5$ & $0.4-0.8$ & 25 & Glucose/NaAc & 10 & 20 & & 400 & 40 & $\begin{array}{l}4.2 \\
10 \\
-14\end{array}$ & 10 & $\begin{array}{r}95 \\
40 \\
28\end{array}$ & 12 & $\begin{array}{l}81 \\
80 \\
86\end{array}$ & $\begin{array}{l}86 \\
87 \\
89\end{array}$ & $\begin{array}{l}7.6 \\
7.9 \\
5.7\end{array}$ \\
\hline $\begin{array}{r}\text { (Wang et al., } \\
2016 a)\end{array}$ & 8 & 6.0 & 1.5 & 3.5 & 45 & 4.0 & $3.2-3.5$ & $0.4-0.7$ & 25 & $\mathrm{NaAc}$ & 12 & 16 & $7-7.5$ & 400 & 40 & 15 & 10 & 26.7 & 25 & 83 & 91 & 5.4 \\
\hline (Li et al., 2008) & 4 & 8.0 & 2.0 & 3.0 & 60 & 1.8 & 3.5 & $0.2-0.5$ & 21 & $\begin{array}{l}\mathrm{NaAc} \\
\text { Propionate/NaAc: } 1 / 1 \\
\text { Proponate/NaAc: } 2 / 1\end{array}$ & 16 & 22 & $7.3-8 !$ & 300 & 35 & 12 & 9 & 25 & $\begin{array}{r}68 \\
60 \\
58 \\
\end{array}$ & $\begin{array}{l}53 \\
-63 \\
-79 \\
-\end{array}$ & $\begin{array}{r}81 \\
94 \\
97\end{array}$ & $\begin{array}{l}8 \\
-6.5 \\
3.5 \\
-3.5\end{array}$ \\
\hline $\begin{array}{r}\text { (Meyer et al., } \\
2005)\end{array}$ & 5 & 6.0 & 1.95 & 3.1 & 43 & 3.0 & & $0.4-0.5$ & & $\mathrm{NaAc}$ & 10 & 15 & $7-7.5 \dot{i}$ & 136 & 18 & 11 & 8 & 13 & & & 100 & 3.5 \\
\hline $\begin{array}{r}\text { (Jia et al., } \\
2013 b)\end{array}$ & 15 & 6.0 & 1.5 & 3.0 & 70 & 7.5 & $3.0-3.3$ & $0.4-0.8$ & 25 & Glucose/NaAc & 12 & 20 & $7-7.5 \mathrm{i}$ & 350 & 50 & 5 & 7 & 70 & 12 & 92 & 82 & 4 \\
\hline $\begin{array}{r}\text { (Wang et al., } \\
2015 \text { ) }\end{array}$ & 8 & 6.0 & 3.0 & 2.5 & 20 & 3.0 & 3.0 & 1.0 & & $\mathrm{NaAc}$ & 14.6 & 10.9 & 7.2-8 & 254 & 65 & 6 & 4 & 42 & 26 & 49 & 94 & 10 \\
\hline This Study & 4 & 6.0 & 2.0 & 4.0 & 20 & 2.8 & 3.0 & 0.5 & 22 & $\mathrm{NaAc}$ & & & $7-8$ & 200 & 40 & 10 & 5 & 20 & 100 & 100 & 100 & 1.2 \\
\hline
\end{tabular}

